\title{
Remote and Technology-Based Dialogic Development during the COVID-19 Pandemic: Positive and Negative Experiences, Challenges, and Learnings
}

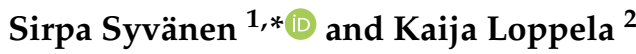

1 Work Research Center, Faculty of Social Sciences, Tampere University, Kalevantie 4, 33014 Tampere, Finland

2 School of Health Care and Social Work Seinäjoki, Seinäjoki University of Applied Sciences, Kampusranta 11, 60320 Seinäjoki, Finland; kaija.loppela@seamk.fi

* Correspondence: sirpa.syvanen@tuni.fi; Tel.: +358-40-1901315

Citation: Syvänen, S.; Loppela, K Remote and Technology-Based Dialogic Development during the COVID-19 Pandemic: Positive and Negative Experiences, Challenges, and Learnings. Challenges 2022, 13, 2. https://doi.org/10.3390/ challe13010002

Academic Editor: Susan L. Prescott

Received: 8 December 2021

Accepted: 18 January 2022

Published: 20 January 2022

Publisher's Note: MDPI stays neutral with regard to jurisdictional claims in published maps and institutional affiliations.

Copyright: (C) 2022 by the authors. Licensee MDPI, Basel, Switzerland. This article is an open access article distributed under the terms and conditions of the Creative Commons Attribution (CC BY) license (https:// creativecommons.org/licenses/by/ $4.0 /)$.

\begin{abstract}
This study aimed to analyze the challenges, learning experiences, and effects of the COVID-19 pandemic in a social, healthcare, and special education development project financed by the European Social Fund. The theoretical framework of the project relied on the theories of dialogic development and leadership. The method was participatory action research using data collected from various assessments and a questionnaire. Reports of neutral, negative, and positive experiences among two participant groups of the project—-the implementers and pilot organizations—in remote work, devices and applications, and remote and technology-based development processes, were recorded. Both participant groups reported increased pressure at work, social isolation, professional loneliness, and improved work control and efficiency. The pilots have learned the development method, and development has been able to continue by utilizing technology despite the pandemic. Development through technology was more difficult, and new dialogic interaction tools have been created. The project was most effective with regard to leadership, teams, renewal, and information flow. There is a need for wide-ranging dialogues with various working life actors when outlining the ways in which future work will be carried out and to reflect on how remote work, technology, and digitalization affect well-being at work, social relations, and leadership.
\end{abstract}

Keywords: dialogic development; participatory action research; remote and technology-driven workplace development; well-being at work; productivity; renewal; multi-actor assessment

\section{Introduction}

Workplaces all over the world have had to adjust to new ways of working in contexts in which new technology, devices, and applications play an important role. De' et al. [1] studied and presented possible scenarios for the digital surge and the accompanying problems. Digitalization is leading organizations to work from home. Remote work raises important issues, such as work allocation, collaboration, motivation, leadership, work overload, pressure at work, and presenteeism. Well-being at work might also be negatively affected by issues related to increased technostress. Miele and Tirabeni [2] studied how employees use and incorporate digital technologies into their daily lives from the point of power and control.

The motivation for the study stemmed from the authors'-experienced action researchers-desire to assess how the COVID-19 pandemic (the Pandemic from here on) has contributed to the implementation of a participatory action research (PAR) development project (Project from here on), which has collaboratively developed organizations in the social, health, and special education sectors during the Pandemic. The Project is funded by the European Social Fund (ESF)/The Finnish Ministry of Social Affairs and Health as a four-year (2019-2022) development project, being nationwide and implemented in nine provinces in Finland. The levels of organizational development are nationwide, 
regional, and organizational. The consortium implementing the Project consists of two universities, two universities of applied sciences, and seventeen municipal and three private organizations (hereinafter pilots). The Project staff consists of 16 experts (e.g., senior researchers, principal lecturers, lecturers, and workplace developers), each responsible for their pilot organizations. There are 20 pilot organizations from the public (16) and private sectors (4), which provide elderly (8) and child, youth, and family welfare services (e.g., child protection and family services (10) and special education (2)). The common development goals of the Project are to improve and apply meta-skills related to dialogue, reflection, resilience, and technology, while improving the leadership and development of well-being and occupational safety. The development targets, structure, methods, and tools were recorded in the joint, official ESF/EURA2014 Project plan (December 2018, duration 2019-2021), which provided the funding to the Project's consortium. The development targets and activities of the Project have been tailored to each pilot organization.

One of the key features of PAR is that it considers and reacts immediately to various changes in the operational context [3-5]. The Project started in 2019, barely one year before the Pandemic began. The key groups (Staff of the Pilot organizations and Staff of the Project) of the Project faced the surprising and rapidly changing situation in the spring of 2020, as the Pandemic began. Restrictions were imposed in March 2020, and the Pandemic affected the implementation of the Project from March 2020 to August 2021, a total of 18 months (hereinafter, the COVID-19 phase). In this changed situation, two pilot organizations stopped participating in the Project, and two new pilots started. In addition, the duration of the Project was extended by one year, with a changed application submitted to the funder in June 2020. Technology and digitalization play a significant role, because the project's organizations as well as the implementation staff (Project staff from here on) started to work and interact remotely during the Pandemic. In terms of Project implementation, the greatest challenges and difficulties have been caused by the long-term restrictions on movement and assembly as well as the remote work recommendations imposed by many different authorities and organizations to ensure health safety. Other considerations included the Pandemic guidelines and constraints by the four implementers of the Project as well as the 20 pilot organizations involved in the development work (i.e., the service units, workplaces, professional groups, and teams).

By its methodological nature, the development approach of the Project is holistic, collaborative, concept-driven, and research-assisted [3,5-9]. The key principles of the development method are the cooperation of different parties, the principles of democratic dialogue $[3,5,7,9]$, and dialogue $[10,11]$, and conventionally it has been based on immediate interaction and organizational learning spaces [4,9,12-14]. Before the Pandemic, the dialogical development method and development structure of the Project (hereinafter, traditional phase) were to be based on the direct interaction and dialogue of different parties through face-to-face meetings and development events. Meetings, multi-professional development groups and encounters, physical, social, and mental dialogue spaces, as well as activating and participatory tools and methods played a key role. [9] The theoreticalmethodological framework of this concept-driven $[15,16]$ and research-assisted organization development Project (Figure 1) relied on the theory of dialogic leadership, organization, and development $[12,13]$.

The theoretical framework used the quality of working life questionnaire of dialogic leadership model (see Figure 1) have been applied and tested in several Finnish PAR projects $[12,13,17]$, in which democratic dialogue and the principles of dialogue $[10,11,18]$ have played essential roles. In the theoretical framework, the four contextual and individual core factors, collaboration and dialogue, motivation, control of work and skillfulness, and renewal (including learning, creativity, and development), fill those essential roles and have an initial impact on work productivity and satisfaction before affecting performance (including economy, productivity, and effectiveness), innovativeness, and quality of working life through participatory leadership and collaborative organization structures. In dialogic development, the four main principles of dialogue-listening, respecting, voicing, 
and suspending - are applied. Generative dialogues $[10,11]$ require dialogic capabilities, critical reflection, and an open and confidential conversation culture [13].

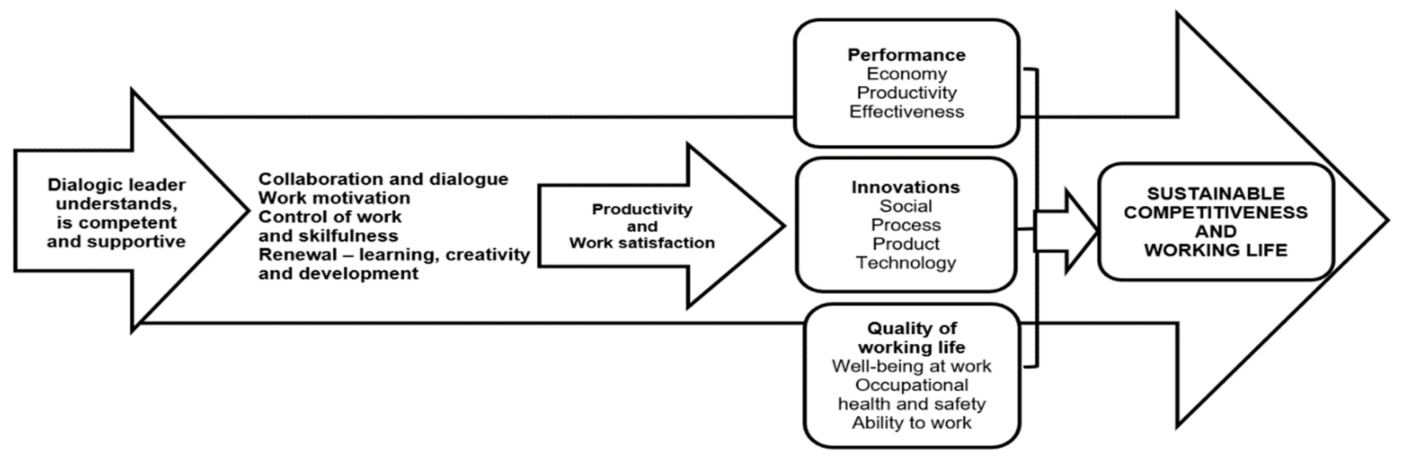

Figure 1. The multidisciplinary framework of dialogic leadership and development (adapted and modified from [12]).

The nature of the study was evaluation research, i.e., program evaluation, and the process and project evaluation included various techniques, methods, and models suitable in the pandemic context. The Project participants' performance in this study was targeted in three different phases: (1) traditional or conventional (traditional hereinafter), (2) transition, and (3) COVID-19. The participant groups of evaluators were: (1) the pilot organizations-the entire staff of the 18 pilots, including employees, various vocational professions, and superiors working at various hierarchical levels; and (2) OD practitioners, i.e., the Project's staff (hereinafter the Project staff, 16 persons). Qualitative and quantitative materials were collected through quality of working life questionnaire, Webropol Survey inquiries, and multi-actor evaluation workshops. The assay methods were frequency analysis and content analysis.

The perspective of this empirical study is based on participatory action research and democratic dialogue methodology, answering the need for further research stressed by Kalliola and Mahlakartano [4]. They utilized several qualitative literature analyses and their own experience. The authors called for empirical research. Technological change presents challenges to work organizations, employers, employees, and various professions, which have had to renew their modes of operations, actions, and work processes during the Pandemic. This has affected most public sector organizations characterized by professional, value-oriented work, including nurses, teachers, and social workers. Additionally, public work organizations and professionals have been forced to learn how to manage change flexibly and continuously. The methodological grounding of the development lies in a conventional dialogic OD model. In 2013, Gilpin-Jackson [19] summarized the following main features of the model (Table 1).

The features presented in Table 1 were studied in the exceptional circumstances and developing environment caused by the Pandemic. The most different development circumstance based on the authors' earlier projects are remote and technology-based development interaction and processes, methods, tools, and spaces.

Table 1. Conventional concept-driven and research-assisted (PAR) dialogic organizational development (originally by Gilpin-Jackson 2013, modified for this study).

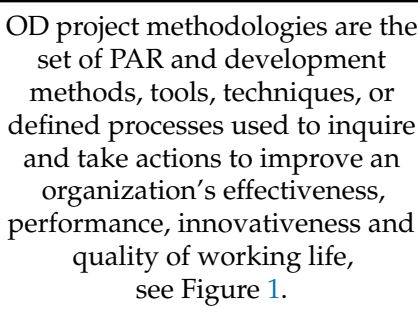

Third-generation OD methodologies and tools. 
Table 1. Cont.

\begin{tabular}{|c|c|c|}
\hline $\begin{array}{l}\text { 2. Goal of OD project process, } \\
\text { approach, or inquiry }\end{array}$ & $\begin{array}{l}\text { OD project is a full cycle of PAR } \\
\text { and actions taken to improve } \\
\text { organization's effectiveness, } \\
\text { performance, innovativeness and } \\
\text { quality of working life, } \\
\text { see Figure } 1 .\end{array}$ & $\begin{array}{l}\text { Emergent self-organizing around } \\
\text { a shared vision of the future } \\
\text { created in conversation and } \\
\text { interaction. A focus on acting on } \\
\text { opportunities and potential in the } \\
\text { organization system. }\end{array}$ \\
\hline 3. Type of OD practice & $\begin{array}{c}\text { OD project practice is the } \\
\text { professional exercise of } \\
\text { organizational development using } \\
\text { a variety of quantitative and } \\
\text { qualitative PAR and } \\
\text { OD methodologies }\end{array}$ & $\begin{array}{l}\text { Methodology-centered where } \\
\text { various dialogic methods define } \\
\text { the OD project. }\end{array}$ \\
\hline $\begin{array}{l}\text { 4. Philosophical orientation } \\
\text { to practice }\end{array}$ & & $\begin{array}{l}\text { Knowledge is emergent and } \\
\text { constructed from real-time } \\
\text { social interactions. }\end{array}$ \\
\hline 5. Role of OD practitioner & $\begin{array}{c}\text { Subject-subject relationship } \\
\text { of PAR }\end{array}$ & $\begin{array}{l}\text { Facilitator who recognizes that } \\
\text { their presence influences } \\
\text { knowledge creation. }\end{array}$ \\
\hline 6. Source of OD & PAR interventions. & $\begin{array}{l}\text { Interventions are co-created by all } \\
\text { involved participant groups and } \\
\text { especially through } \\
\text { self-organizing. }\end{array}$ \\
\hline $\begin{array}{l}\text { 7. Practitioner influence } \\
\text { on implementation }\end{array}$ & $\begin{array}{l}\text { PAR interventions are the actions } \\
\text { and methodologies within an } \\
\text { OD project. }\end{array}$ & $\begin{array}{l}\text { Zero or limited influence, } \\
\text { interventions are implemented } \\
\text { through self-organization } \\
\text { of participants. }\end{array}$ \\
\hline
\end{tabular}

The research interest was to analyze the challenges, learning experiences, and effects of the COVID-19 pandemic on the Social and Health Care and Special Education Development Project's (2019-2022) dialogic development work. The particular interest is methodological and based on the following question: Is it possible to apply a Scandinavian dialogic and collaborative development model $[3,4,6,7,12,13,18,20]$ remotely and through technology? The study concentrates on analyzing the interaction, dialogue, and learning possibilities, spaces, and tools in the remote period of the Project participants using various qualitative and quantitative evaluation materials. We combined many aspects and actors working and collaborating during the Pandemic, as various actors developed their dialogical working life, organizations, workplaces, teams, work, and services. These groups were (1) participating pilot organizations and (2) implementers (Project staff, researchers, experts, and workplace developers). Pilot organizations' staff represents the management, employees, and various professional groups. These two participant groups were in a collaborative and dialogic subject-subject relationship [3,21] while carrying out the Project, developing, and solving problems. The research questions that guided the study are as follows:

1. What are the neutral or positive experiences of the Project's parties, working conditions, and mutual collaboration during the Pandemic period?

2. What are the negative experiences and challenges of the participants of the Project's dialogic development caused by the Pandemic?

3. What are the main learning experiences of the Project's dialogic development during the Pandemic?

4. What are the effects of the Project's dialogic development?

For the literature review, a keyword search was performed with the keyword "COVID19", resulting in 697 hits. According to the review, the Pandemic has had a cross-cutting impact on all aspects of society. Studies and questionnaires have focused mainly on the education, research and training [22,23], and social and healthcare [24,25] sectors. Studies have addressed the impact of remote work and technology [24,26-28], distance schooling, and remote study [29]. In particular, the well-being of teachers, principals, and university professionals at work has been mapped using various questionnaires related to the effects of the Pandemic [30-32]. Particularly common were studies of well-being and pressure at 
work on an individual level [24,26-28,33]. General themes among researchers included the features of future work, especially remote work and remote working [34,35], and leadership during the Pandemic [25,36-38]. Many articles and publications have concentrated on remote work associated with increased digitization and technology, with topics such as the proliferation of remote work and working during the pandemic [1,2,39-44]. During the COVID-19 pandemic, the use of digital technologies has increased because of social distancing norms and lockdowns $[1,44]$. The literature review revealed fewer publications during COVID-19 on workplace development [39,45], learning, or the renewal of work communities or work [46,47], except for the technology and digital leap [39,40]. A digital leap, together with remote work, was reported, with a particular focus on teachers' or other academic professionals' work, well-being at work, distance schooling, or remote university, teaching, research, and learning [22,23,29-32,48,49].

\section{Methods}

The use of questionnaires as a data collection method is an essential part of this approach [13]. The quality of working life questionnaire has been utilized for pre- and post-measurement in several PAR development projects of the authors $[5,12,13]$. The questionnaires act as significant mirrors for reflective processes: the strengths and weaknesses of the working communities and the variables that need development in the workplaces can be identified through the results. The questionnaire was included in the Project's original implementation plan, and it consisted of many questions that were used in this study (e.g., technology in one's own work and in the work community, the effectiveness of development work). One new question was added to the post-measurement questionnaire to examine the respondents' experiences of the impact of the COVID-19 pandemic on their work, work community, management, and clients.

The quality of working life questionnaire $[5,12,13,17]$, which was conducted as a pre-measurement in 2019 and as a post-measurement in 2021, contained the following 14 thematic categories:

1. Features of work, control of work, workload, pressures at work;

2. Factors of well-being at work community, atmosphere, and operating principles;

3. Learning, renewal, development, creativity;

4. Teams, team self-direction;

5. Features of the work community;

6. Employer's responsibilities, working environment and conditions, psychosocial risks, conflict management;

7. Management, supervisory work, and leadership style;

8. Power, responsibilities, and division of labor;

9. Objectives: values, basic tasks, goals, 'rules of the game';

10. Influence and participation;

11. Information flow, communication, interaction;

12. Feedback and rewarding;

13. Satisfaction;

14. Effectiveness of collaborative development (Question 49: What kind of effect has the collaborative and dialogic development had?).

In this study, we only analyzed the thematic categories of the questionnaire where the qualitative analysis revealed the main results. Those categories were: (1) pressures at work on the individual level: workload, pressures at work, ethical and mental burden of work; (2) leadership style; (3) features of workplaces; (4) satisfaction; and (5) the effectiveness of collaborative and dialogic development. The results of the frequency analyses were combined from the five Likert options (1-5) into option 1 (Very good effectiveness/Very satisfied/Fully agree, etc., \%) and option 2 (Quite good effectiveness/Quite satisfied/Somewhat agree, etc., \%).

Open-ended questions in the questionnaire were as follows: (1) What do you want to say about leadership? (Question 25); (2) What do you think about the role of technology 
and digitalization in your work? (Question 27); (3) How has the COVID-19 pandemic affected your work, work community, leadership and management, and interactions with customers? (Question 50); and (4) The word is free (Question 57). Among the open-ended questions, only questions about technology and digitalization as well as COVID-19 were analyzed, because they were the most relevant for answering the research questions.

In order to assess more impacts of the Pandemic, evaluation workshops were organized for the supervisors and employees of the pilot organizations in the autumn of 2021, in which they assessed the impact of the Pandemic on the development and implementation of the Project.

The self-reflection and group evaluations were executed from February 2020 to September 2021, generating qualitative and quantitative data and materials. In the spring of 2020, just before the start of the Pandemic, the Project's first evaluation process was conducted as a self-evaluation of the Project staff. The development work had been ongoing for one year and two months, with 15 pilot organizations and their 39 teams or workgroups. The evaluation was performed by mirroring the development work in the development plans. With a case study narrative, it was possible to chronologically present all of the development work carried out in the traditional, transition, and COVID-19 phases. The case study consisted of a brief presentation of the Project pilots' plans, organization-specific development needs and goals, and Loppela's (2004) participatory development method, called Toward better work and well-being by discussion [7].

Content analysis was inductively used to describe the phenomenon under study. The inductive strategy proceeded based on the data generated from the research data, from individual to general. The qualitative material followed a thematic design, which began with an inductive analysis involving the reduction in the material, i.e., the coding of the material related to the research task. The experiences of the pilot organizations' staff were first recorded in lists and then reduced. In the next phase, the data were grouped based on their similarities and differences, and groups with the same meaning were combined into sub-content categories. These categories were named with descriptive words as the upper content categories or sections as mutually exclusive categories. The qualitative content analysis is reported as a summary of the thematic categories [50] (pp. 117-146). Table 2 presents a summary of the Project evaluations.

More about the methods, data gathering techniques, qualitative and quantitative materials, and analyses are presented in Table 2.

Table 2. Evaluations: methods, time, data-gathering methods, actors, questions, and analyses.

\begin{tabular}{|c|c|c|c|}
\hline . & $\begin{array}{l}\text { Evaluation: Time, } \\
\text { Methods, Analyses }\end{array}$ & Participants & Questions \\
\hline $\begin{array}{l}\text { (1) Traditional phase } \\
\text { Before Pandemic } \\
01 / 2019-02 / 2020\end{array}$ & $\begin{array}{c}01-02 / 2020 \\
\text { Self-evaluation. } \\
\text { Content analysis. }\end{array}$ & $\begin{array}{l}\text { The project staff } \\
\qquad \mathrm{N}=16\end{array}$ & $\begin{array}{c}\text { Questions: } \\
\text { (1) What kinds of development targets have been } \\
\text { agreed to by the pilot organizations? } \\
\text { (2) How well these targets have been reached, and } \\
\text { what has been achieved through them? } \\
\text { => Results: development goals (1-2) } \\
\text { (3) If the targets have been reached, what has } \\
\text { supported them? What are the positive effects? } \\
\text { => Results: positive effects, promotors } \\
\text { (4) If the targets have not been reached, what has } \\
\text { prevented them? } \\
\text { (5) Have there been experiences of development } \\
\text { activities having negative effects in the } \\
\text { workplaces? If so, what kind? } \\
\text { => Results: obstacles and negative effects }\end{array}$ \\
\hline
\end{tabular}


Table 2. Cont.

\begin{tabular}{|c|c|c|c|}
\hline$\cdot$ & $\begin{array}{l}\text { Evaluation: Time, } \\
\text { Methods, Analyses }\end{array}$ & Participants & Questions \\
\hline $\begin{array}{l}\text { (2) Transition phase } \\
\text { At the beginning of } \\
\text { the restrictions } \\
03-08 / 2020\end{array}$ & $\begin{array}{l}\text { 04-06/2020 } \\
\text { Common creative process } \\
\text { 'brainstorm' at Consortium } \\
\text { meetings and workshops } \\
\text { using OPERA method. }\end{array}$ & $\begin{array}{l}\text { The project staff } \\
\qquad \mathrm{N}=16\end{array}$ & $\begin{array}{l}\text { Question: } \\
\text { How to continue the SH project during Covid-19 } \\
\text { and under the several restrictions (national, } \\
\text { implementers, pilot organizations, funders etc.)? } \\
\text { => Results: plan for the transition phase. }\end{array}$ \\
\hline \multirow[t]{3}{*}{$\begin{array}{l}\text { (3) Covid-19 } \text { phase } \\
\text { During pandemic restrictions } \\
09 / 2020-10 / 2021\end{array}$} & $\begin{array}{c}\text { 03/2021-10/2021 } \\
\text { Quality of working life } \\
\text { questionnaire, self-evaluation, } \\
\text { individual reflection. } \\
\text { Content analysis } \\
\text { Frequency analysis. }\end{array}$ & $\begin{array}{l}\text { The pilot organizations' staff: } \\
\text { (1) Children protection and } \\
\text { family services care } \mathrm{N}=172 \\
\text { (2) Elderly care services } \\
\mathrm{N}=53\end{array}$ & $\begin{array}{c}\text { Question: } \\
\text { (1) What do you think about the role of } \\
\text { technology and digitalization in your } \\
\text { work? (Q: 27) } \\
\text { (2) How has Covid-19 affected your work, work } \\
\text { community, management and leadership, and } \\
\text { interaction with customers? (Q:50) } \\
\text { (3) What kind of has been the effectiveness of } \\
\text { dialogic and collaborative development? (Q: 49) }\end{array}$ \\
\hline & $\begin{array}{l}\text { 09-10/2021 } \\
\text { Multi actor assessments, } \\
\text { evaluation workshops. } \\
\text { Content analysis. }\end{array}$ & $\begin{array}{l}\text { The pilot organizations' staff: } \\
\text { (1) Management groups } N=7 \\
\text { (2) Multi professional } \\
\text { employee groups } N=11\end{array}$ & $\begin{array}{l}\text { Question: } \\
\text { How has Covid-19 affected collaborative and } \\
\text { dialogic development in your workplace? }\end{array}$ \\
\hline & $\begin{array}{l}\text { 09-10/2021 } \\
\text { Webropol inquiry, individual } \\
\text { self-reflections. } \\
\text { Content analysis. }\end{array}$ & $\begin{array}{l}\text { Project staff } \\
\quad \mathrm{N}=10\end{array}$ & $\begin{array}{l}\text { Questions: } \\
\text { (1) What kind of have dialogic and collaborative } \\
\text { development have been during the } \\
\text { Covid-19 pandemic? } \\
\text { (2) What have been the main lessons and insights } \\
\text { for you about collaborative and dialogical } \\
\text { development in SH Project during the } \\
\text { Covid-19 pandemic? } \\
\text { (3) What have been the main promoters? } \\
\text { (4) What have been the main obstacles? }\end{array}$ \\
\hline $\begin{array}{c}\text { Case study combining } \\
\text { phases } \mathbf{1 - 3} \\
01 / 2019-08 / 2021\end{array}$ & Content analysis. & $\begin{array}{l}\text { Case study, narrative of } \\
\text { development in three pilot } \\
\text { organisations of one } \\
\text { implementer. }\end{array}$ & $\begin{array}{l}\text { Description of the collaborative and dialogic } \\
\text { development, methods and tools, processes, } \\
\text { and phases. }\end{array}$ \\
\hline
\end{tabular}

\section{Results}

\subsection{Traditional Phase-Evaluation of the Planned Development of the Project}

The results of the Project's interim evaluation provided initial information on how dialogic development with expert support has promoted progress in the pilot organizations. At the mid-term of the Project in the spring of 2020, the process was assessed through the developers' self-evaluation. The results of the evaluation indicated that various dialogical mapping and development methods have been used in work communities to highlight areas for development. The extensive quality of working life questionnaire conducted at the beginning of the Project was also an important tool [12,17].

Development objectives. The most common development objectives or goals focusing on the factors supporting well-being at work and principles in the organization are: (1) dialogue, communication and interaction, information flow and meetings; (2) community and teamwork; (3) orientation; (4) influence and participation; (5) "rules of the game"; (6) features of work and control of work (i.e., physical, mental, and ethical workload, the rushing and limitations of work); (7) utilization of expertise; (8) supervisory work, management, and leadership; and (9) well-being at work and occupational safety. Many of these objectives were achieved. They were initially set out to build a relationship of trust. In connection with the development of occupational safety, for example, safety equipment was ordered for employees, and its functionality and usability were tested. For these goals, concrete organization-based development acts were carried out and evaluated. By the spring of 2020, every pilot organization had made progress toward the objectives. Several of them were achieved, and the development processes also started well. The general observation was that the realization of many goals was facilitated by the external experts, 
the Project staff. Clear, functional, and systematic methods were used, and they supported both the highlighting of development goals and the achievement of goals through concrete development measures. Dialogue was practiced as part of development and was found to increase transparency and support a positive environment. The commitment of supervisors and employees was perceived as good and important.

Obstacles, negative experiences, and effects. The general observation was that no major obstacles emerged. In some workplaces, open dialogue was new, and development thus required acclimatization and caused some confusion in the beginning for both the supervisor and the employees. Some workplaces were under severe time pressure, and thus meaningful development work posed an additional challenge; for example, the use of working time and the convening of as many employees as possible at the same time. Participation in the development project seemed to add pressure to a situation in which the team's resources for the basic task were already tight. In some pilot organizations, the staff felt the time for joint discussion to be absent from client work. This consistently resulted in additional work for the authors of the shift lists when employees needed to be detached from Project events while ensuring there were enough employees in the field. Some members of the management team did not have enough time to participate in the development meetings, and they experienced guilt that the agreed-upon meetings had to be postponed or canceled.

Negative effects. Generally, staff of the Project considered that development activities have not had particular negative effects. However, a few individual issues were raised; the awkward, difficult issues that were raised regarding negative emotions because, earlier, difficult issues and problems were not dealt with openly together. However, these were considered in the development meetings. Shift arrangements and the handling of acute customer situations rhythmized employees' opportunities to participate in the workshops.

Promoters and positive effects. The general conclusions were that the dialogue between employees and supervisors clearly increased, and dialogic development was a great success. Being visible, transparent, and concretized in the joint development meetings and workshops was important. The importance of meta-skills emerged. Development methods provided space for open and equal discussion in the team and increased the importance of meetings. Discussions about various organizational phenomena and factors, openness, and trust increased. Dialogue was studied and perceived as important, and the participants desired to utilize it in further development work. Meetings often began with a tune-up and a round of hearings that involved everyone as participants in a future development event.

\subsection{Transition Phase-What Happened When the Pandemic Hit?}

The Pandemic intensified in Finland in March 2020. One pilot of the elderly care services (home care) was stopped because of the Pandemic, and almost all of the pilots had to cancel or reschedule development sessions. The dialogic development model was changed to the remote and technology-driven model.

"The project has had to be justified and somehow apologized for bothering the work community with matters related to the project, even though they have the experience that even more important, acute customer issues are not done, and at least not taking any breaks or recording properly in their own work."(Workplace developer, Project)

There was also a desire to continue the Project and its development, and new pilots were launched. In the pilot organizations, internal developers ("fiery souled internal developers" or "bearers of responsibility") were found, the home care teams were forced to become self-directed, and cooperation between the different Project pilots started. The entire consortium and the Project staff with its four different implementers moved to remote working and development, and interaction with pilots continued through technology. Among the pilot organizations, staff excitement and motivation decreased, and they were forced to focus attention on basic tasks. The Project became overshadowed. 
"Now, there is a feeling and concern on the surface that the field cannot be done very well and continuous development exhausts work communities. This brings me as a developer an ethical conflict and in a way eats away the motivation to do development work. I wonder how the development of work in everyday life a more natural part of the whole structure could be, neither detached, nor temporary, nor a necessary evil imposed by the employer that tears at many different goals and objectives."(Workplace developer, Project)

In this transition phase, from April to June 2020, the Project staff organized a creative brainstorming workshop to react rapidly to the Pandemic. The brainstorming was carried out using the OPERA method [51]. There were four phases, and the following ideas emerged (Table 3; only the ideas that were realized are presented).

Table 3. The results of creative brainstorming at the beginning of the transition phase.

\begin{tabular}{|c|c|}
\hline 1. Pandemic spring greetings & $\begin{array}{l}\text { Personal remembrance for each employee, } \\
\text { workplace, team, management team, } \\
\text { development team. Flowers, cake, chocolate, } \\
\text { cards, face shields, that developers experience } \\
\text { good. A concrete memory that makes someone } \\
\text { feel like someone is thinking "Me" or "Us". } \\
\text { Delivery by letter, including encouraging and } \\
\text { empowering messages, accompanied by } \\
\text { development tasks. }\end{array}$ \\
\hline 2. Enhancing webinars & $\begin{array}{l}\text { In connection with the theme of wellbeing at } \\
\text { work, which can be viewed according to } \\
\text { workplaces' own schedule. Webinars } \\
\text { implemented together with the Finnish } \\
\text { Municipal Development Program. }\end{array}$ \\
\hline 3. Support for supervisors & $\begin{array}{l}\text { Concrete tips for supervisors on how to } \\
\text { support the coping of their subordinates. } \\
\text { Lectures for workplaces. }\end{array}$ \\
\hline 4. Tips to survive in an exceptional situation & $\begin{array}{l}\text { Collecting tips for different pilots, professional } \\
\text { groups, teams to cope with an } \\
\text { exceptional situation. }\end{array}$ \\
\hline 5. Monthly letters & $\begin{array}{l}\text { A joint consortium monthly letter will be sent } \\
\text { by email, recipes for the joy of work for the } \\
\text { pilots. Can be found on the project's website. }\end{array}$ \\
\hline 6. Tips for strengthening and relaxing & $\begin{array}{l}\text { Material bank and various options for } \\
\text { relaxation and recovery. }\end{array}$ \\
\hline
\end{tabular}

In the transition phase, greetings from the developers (e.g., flowers, chocolate, development tasks) and the support and help from managers (spars) were important Project activities which provided support to the pilots. The feelings among the Project staff during the transition phase were positive.

"We have coped well and did our work and interaction with the pilots well."

Survival in the new situation of the Pandemic and its restrictions was facilitated by good adaptability and an open-minded attitude. A common attitude was to focus on what was possible and not on problems and obstacles. The Project also gave significant support and assistance to the pilot organizations, which increased motivation.

\section{"Project activities did not 'freeze', and remote development was adapted where it was possible."}

Generally, the Project staff felt that remote work and technology-driven collaborative and dialogic development was more difficult, but possible. Remote development sessions containing the four principles of dialogue-listening, appreciation, direct speech, and waiting-were carried out using different technologies, devices, and applications. 


\subsection{Case Study: Developing Dialogical Workplaces during the Traditional, Transition, and COVID-19 Phases}

Traditional phase. The development model Toward better work and well-being by discussion [7] was based on dialogic and reflective development conducted jointly by supervisors and employees, simultaneously considering the perspectives of employees, employers, and customers. A separate development plan was made for each pilot organization, including goals, concrete measures, responsible persons, and schedules. In each development meeting, dialogic and reflective self- and process evaluations were carried out. The various phases of the joint development were carefully documented using a bundle of documents. The model facilitated the evaluation of the outcomes and made them visible to all participants.

The development with three pilot organizations providing elderly care services started in the late spring and early autumn of 2019. Start-up negotiations were held at the beginning of the year. In the first development sessions, the pilots were introduced to the development method. An extensive quality of working life questionnaire was conducted as a premeasurement, and the results were reviewed systematically. While interpreting the results, well-functioning factors and factors requiring development were highlighted, and joint dialogues were arranged. A common development theme for all pilots was dialogue. Familiarity with the phenomenon of dialogue was induced, both by theory and through various functional exercises (i.e., dialogue cards and group reflections).

Transition phase. The development was carried out face-to-face according to the plan until March 2020, when development was interrupted by the Pandemic. Contact was maintained with the Project supervisors from March 2020 to September 2021, mainly by email and telephone. Furthermore, a series of slides supporting entry into force was prepared and sent to the pilots in June 2020, as well as a reflection task related to the Pandemic situation and coping in exceptional circumstances. The participants were also given Recipes for the Joy of Work in June-August as a gift. In September 2020, a joint Microsoft Office 365 Teams meeting was held for the supervisors of all pilots, and a consensus was reached on how the development work would be continued. The groups decided to continue the development in each organization remotely through Teams. The next sections describe the development of the three pilot organizations providing services for the elderly.

Six to eight development meetings in three pilots were held during the break in the Project from March to August 2021 because of the Pandemic. After that, the meetings were mostly held remotely via Teams from September 2020 until May 2021. In the autumn of 2021, the meetings mostly became face-to-face again. Remote sessions were the biggest change compared with the planned face-to-face development. However, the pilots had already taken a digital leap in their own basic functions. Prior to the Pandemic, the development of all three pilots was carried out in different ways. The principles of dialogue were practiced and learned earlier for application. The development goals were concretized as follows:

- Improving the internal flow of information;

- Providing better and more information to partners and customers;

- Establishing principles, "rules of the game" for different things, e.g., for communication, and meeting practices to support successful communication and for shift planning;

- Increasing open interaction, cooperation, and reciprocity and enabling everyone to participate and develop dialogue, direct speaking and listening skills;

- Improving equal treatment for clients;

- Introducing and learning to use new online platforms and IT equipment;

- Processing and utilizing customer feedback in the development of services;

- Assessing a new patient information system to ensure the use of consistent phrases;

- Developing interprofessionality;

- Assessing better dissemination of the information provided by training and conferences to develop skills;

- Developing meeting practices; meetings should be more frequent, scheduled, and planned;

- Reducing workload and joint handling of workload. 
After a joint reflective dialogue discussion, concrete measures were identified for each objective and development experiment. They were also regularly evaluated. Most of the goals were achieved successfully, and some new ones were agreed on after the evaluation. Some of the goals required cooperation with stakeholders; therefore, development was slower, and it was carried out in a step-by-step process.

COVID-19 phase. The next sections describe the effects of the Pandemic on technologybased development. The effects of the Pandemic were investigated in the autumn of 2020 in a joint evaluation meeting with the leaders of the pilot organizations. The following effects were highlighted:

- The hygiene unit was very helpful and supportive throughout the Pandemic, staying well-informed about current issues;

- The joint dialogue development came to a near-standstill, because all the time and energy was spent on overcoming the necessary, concrete tasks and making special arrangements in the Pandemic period; for example, considering different methods of protection;

- There were challenges with the adequacy of employees; for example, the required absence of employees' children from care places due even to mild flu symptoms caused employee absences;

- Employees were trained to track down potential COVID-19 infection chains. At that time, however, no COVID-19 virus infections were detected in that locality;

- New service chains were launched to improve the quality of patient care;

- There was a digital jump in operation during spring and summer: the doors were closed, operations partially switched to remote working, and customer contacts were arranged in advance;

- In the spring, the receptions became mainly telephone receptions, and video connections were also utilized in the receptions. Teams was introduced into meetings and internal communications (e.g., training bulletins);

- Home-based services were added, and the assessments were performed differently from before in the clients' home; some home care staff were helpful, and Skype calls were utilized;

- Staff meetings were held on Teams, half of the time in-person and half of the time using remote schedules, and protective equipment was used.

In the autumn of 2020, after a development break of six months, the negative and positive effects, coping strategies, and activities at the work community level caused by Pandemic were assessed by three pilot staff. The results of the evaluation are presented in Table 4.

Pilots with more employees had more development needs than the smaller pilots both before and after the Pandemic. In the pilots with the worst results in the pre-measurement questionnaire in general and in management and well-being in particular, the Pandemic had the most detrimental effect on development activities, stopping it almost completely. Dialogue was found to have declined in a pilot in which it had been low even before the Pandemic. Furthermore, organizational change during the Pandemic appeared to have partially weakened development activities. Pilots that had regular meetings before the Pandemic were better at coping; even during the Pandemic, information and dialogue were maintained. Management was perceived to support the challenges of the Pandemic period in the pilots in which leadership and management had been at a good level before the Pandemic. The development plan was drawn up, and Project staff helped to develop and gave support, even during the Pandemic. 
Table 4. Positive and negative effects and the coping strategies and activities.

\begin{tabular}{|c|c|c|}
\hline Positive Effects & Negative Effects & $\begin{array}{c}\text { The Coping Strategies } \\
\text { and Activities }\end{array}$ \\
\hline $\begin{array}{l}\text { - genuine digital jump has } \\
\text { been taken; } \\
\text { - the development has continued } \\
\text { during the COVID-19 phase } \\
\text { independently in the workplaces; } \\
\text { - the development plan has } \\
\text { supported pilot organizations } \\
\text { during pandemic; } \\
\text { - progress has been seen in the } \\
\text { direction of goals. }\end{array}$ & $\begin{array}{l}\text { - social isolation is a burden; } \\
\text { - negative COVID-19 information } \\
\text { through the media increased fear } \\
\text { and pressure; } \\
\text { - uncertainty during the } \\
\text { pandemic period; } \\
\text { - mental strain and sick leaves; } \\
\text { - pandemic quarantines } \\
\text { and restrictions; } \\
\text { - coping was in a test while the } \\
\text { workload increased; } \\
\text { - partial transition to } \\
\text { remote working. }\end{array}$ & $\begin{array}{l}\text { - leisure activities-nature, } \\
\text { outdoor activities; } \\
\text { - good team spirit and atmosphere; } \\
\text { - meetings; } \\
\text { - members of the workplaces have } \\
\text { seen each other in person, even if } \\
\text { part of them has been at office and } \\
\text { part of them remote by } \\
\text { Teams application; } \\
\text { - coffee room for two people at a } \\
\text { time, seeing colleagues; } \\
\text { - a good, present and reachable } \\
\text { manager, even in remote working; } \\
\text { - transparency and trust; } \\
\text { - speaking; } \\
\text { - matters are dealt with regularly; } \\
\text { - unit meetings held considering } \\
\text { safety intervals, partly remotely } \\
\text { and partly at the workplace; } \\
\text { - personnel information was good, } \\
\text { pandemic information was } \\
\text { regularly shared and recorded; } \\
\text { - in the nursing meetings, it was } \\
\text { possible to get on the agenda } \\
\text { proposals on the issues to be } \\
\text { discussed in advance; } \\
\text { - remote work has made it possible } \\
\text { to concentrate better and focusing } \\
\text { only one task or issue at time; } \\
\text { - work breaks. }\end{array}$ \\
\hline
\end{tabular}

\subsection{COVID-19 Phase-Summary of the Experiences of the Project Participants}

Experiences of the Pandemic were neutral, positive, and negative among the pilot organization and Project staff. Negative experiences were the most common and had the highest variety. Figure 2 summarizes the theme categories of the qualitative materials results presented in Table 2.

\section{COVID-19}

pandemic, remote work, technology and digitalization Neutral experiences Both groups

\section{Remote working} and meetings individual and collective level Positive and negative experiences Both groups

\section{Technology and} digitalization

Positive and negative experiences Both groups
1) Employer, management and the Project level

- employer responsibilities, management of safety and wellbeing, resource allocation, control of workload

2) Individual level

- work, working conditions, wellbeing at work

3) Team and workplace level (inc., Consortium/Project internal relationships and interaction)

4) Client level

- Pilots: client relationships, services, pilot's staff interaction with clients

- Project staff's interaction with pilots

1) Devices, applications, connections, using technology

2) Remote technology, i.e., Microsoft Office 365, Teams, Zoom

Figure 2. The main results in the thematic categories. 
3.4.1. Neutral and Positive Experiences of Remote Work, Technology, and Dialogic Development: Pilots

Pilot organizations' staff had many positive experiences during the Pandemic and the increased remote working, technology, and digitality it brought about. With the onset of Pandemic restrictions in the spring of 2020, remote working increased, and workplaces responded quickly. Various means, tools, and technologies of remote work were introduced. Distanced meetings also became more common. At the individual level, many of the respondents felt that remote connections worked well in their own workplaces. Participants felt that remote working was more independent and versatile; for instance, in helping to plan and implement their work. While working remotely, work became more flexible when it was possible to plan and do it according to one's needs. Good and renewed operating methods and the opportunity to negotiate remotely with various parties were also welcomed.

"Technology and digitalization are increasing their role and importance in work, even irreplaceable, which is not uncomplicated in an area, where working with people is paramount."

"It also influences the flexibility of working hours, e.g., remote working. It is hoped that this will continue, and that security will be maintained."

In particular, the Microsoft Office 365 Teams application was widely perceived as a very important and central tool through which meetings, contacts, and interactions with various parties were handled during remote working. The use of Teams clearly increased and became more widespread in almost all work communities. The application was perceived as a good and functional tool that facilitated communication and contacts.

"Teams have been used in intra-workplace and inter workplace and customer contacts. Customer work has been handled through Teams, e.g., in the planning of care and services and in care negotiations. Some service providers have also organized training and webinars for work communities through Teams, as well as different groups for different customer groups, such as peer support groups."

In the pilot organizations, technology was seen as a tool that would be more important in the future. The respondents recognized that doing social and health work remotely based on interaction created its own challenges. It was difficult to make or replace face-to-face contacts remotely, especially in customer work.

"Technology and digitalization are increasing their role and importance in work, even invaluable, which is not straightforward in an area, where working with people is a priority."

3.4.2. Neutral and Positive Experiences of Remote Work, Technology, and Dialogic Development: Project Staff

Among the Project staff, there were quite similar experiences of remote work and technology, and a digital leap was realized. The new situation showed that remote work and development is possible, and it succeeded; however, there was a need to learn and use new digital skills and technologies (e.g., platforms, programs, applications, and connections, such as Teams, Zoom, Presemo, and Skype). Developers were also forced to learn new ways to plan and conduct remote development meetings and events.

"Digital leap of all parties throw themselves into the new way of development and the encounters it brought."

"Ideation and use of creativity in technology-mediated and dialogic development."

3.4.3. Negative Experiences and Challenges of Technology, Digitalization, and Dialogic Development: Pilots

Many negative and burdensome issues were raised about technology and digitalization. These included the constant changes brought about by unnecessary technology and inoperable systems and programs that have taken working time away from more 
important tasks. Many also said that they have not been able to influence the introduction and development of the programs. They also felt that the sheer number of digital devices and software led to many passwords needing to be remembered.

"Digital solutions are often meant to make work easier, but sometimes the opposite happens when new software slows things down and makes work harder."

"There is a growing need for digital issues, but their quality makes basic work even more challenging and resource-intensive. It takes more time, the task is handled through several different stages, for example due to cloud services."

The proliferation and use of technology in the workplace was associated with a wide range of physical and mental stressors and problems, such as small and cramped working spaces with poor air quality due to ineffective ventilation. There were also reports of small storage booths in which confidential customer calls had to be handled.

"Many people are in the same room, so they have to talk long calls in storage booths, etc., where the air quality is poor due to dust and lack of ventilation."

Mental strain and aggression were caused by machines, equipment, programs, and connections that did not work properly, operated slowly, or did not work at all on a regular basis. The strain was caused because valuable work time was spent addressing ongoing and miscellaneous problems and disruptions as well as seeking and waiting for help.

"Electronic customer information systems make work easier, but when they crash, work is sometimes almost impossible."

"Digital devices are snapped at every point and their mistakes are corrected by several people."

There were many problems with technology and technological capabilities, connections, know-how, and attitudes.

"Employees do not have their own computers, a total of 1-2 computers available for remote meetings and few and cramped office space, 1-2 people."

"No knowledge to work online, use of different programs."

"For various reasons, the cameras are not kept on-being in a nightgown, the hair is bad, something else is being done at the same time."

Microsoft Teams meetings also involved a wide range of problems related to network connectivity, basic application features (camera, audio, recording), and user attitudes. Next, we present the most common problems encountered during development meetings and sessions arranged by the Project staff.

"Many people gathered at the same screen, so the sound is not heard, and the picture is not visible to everyone."

"Teams at meetings on a mobile phone or computer cannot be reached while remotely at home or at the summer cottage."

"Sounds and images are not displayed. The camera is shooting the ceiling or is turned off."(Project, developers)

Pilot organization staff felt that there was a wide range of problems and challenges that needed to be addressed. The participants acknowledged that the wider and more diverse use of technology required a new kind of expertise, the management of new programs, and connections and a shift to more extensive remote interaction. A hybrid model with both face-to-face and remote appointments and encounters was considered good.

"Pandemic has contributed to the fact that meetings and training are remote through Teams. It is good that this has been possible. In the future, the meetings could be of a hybrid nature, i.e., the meetings would be held physically somewhere, which, if possible, could be attended or, if an obstacle arose, could be attended remotely." 
Technology and digitalization in the work of different professional groups required increased competence, which was reflected in the Project's social and health organizations as different training needs and competence gaps. This was caused by an ever-increasing number of new technologies and programs that were not perceived to be internalized in busy and strenuous work. Many respondents also pointed out that they did not have the resources, especially the time and skills, to keep up with the technological development of hardware, software, and connections. Experiences of inadequacy were generated by constant monitoring of the technological situation, familiarization with new technologies and programs, and further training. The participants also perceived that employers did not provide sufficient and proper familiarization with technology and digitization. In many workplaces, familiarization with new programs and devices remained a personal responsibility and had to be conducted alone, during leisure time, and without pay.

"Technology and various programs play a big role in the work, new ones are coming all the time, orientation and training should be more up-to-date. Now it is only announced that this and this will come into use and in their own time alone they will then learn, through trial and error, to use new programs."

"There was also a call for targeted training to address the specific and current support needs of employees and the different skills gaps. Many pointed out that the availability of technical support in one's own workplace is very poor and slow."

One of the challenges raised was age. Particularly among older workers, there was an increased burden during the Pandemic related to new technology, monitoring technological developments, and applying them to their work.

"For myself, at the age of 60, the takeover of technology and digital is successful in the basics, e.g., Teams, video calling. Otherwise, there is not much enthusiasm, knowledge or understanding. Of course, I learn something new when it is seen as necessary and useful together."

3.4.4. Negative Experiences and Challenges of Technology, Digitalization, and Dialogic Development: Project Staff

Remote and technology-mediated dialogic and collaborative development sessions were seen as much more difficult than traditional face-to-face development sessions and events. Face-to-face encounters based on direct interaction were perceived as the heart of the development; the remote development sessions were not perceived as authentic and could not sufficiently replace the immediate social contacts. Remote connections were not a substitute for strong in-person interactions. There was also less collaboration, and Teams connections did not correspond to physical encounters and interaction. Interactions and collaborations between developers and pilots remained more distant, and technology limited interactive discussions and deeper and genuine dialogues, especially with regard to difficult themes and problems.

Technology clearly narrowed the dialogue and reduced the diversity of dialogue and the use of dialogical means. There was a lack of nonverbal communication; nonverbal communication and information, as well as a variety of weak signals, went unnoticed (e.g., emotions, expressions, gestures, reactions, side effects). The levels of activity, motivation, enthusiasm, and concentration of the participants in the remote contacts were not as high as in immediate contacts, and group processes and group dynamics suffered. There were also difficulties motivating the participants, and some were left out or excluded. Concentration problems and a temptation to do other work at the same time weakened the results or hampered participants' learning, and the loss of alertness decreased mood and caused boredom. Other lessons from remote, technology-based development sessions are presented below:

- Planning of the dialogic sessions: dialogue is different, and conditions for it must be consciously, purposefully, and carefully planned and built;

- Listening: responding requires listening to the participants; 
- Changes and flexibility: implementation must be prepared for various changes. A flexible approach is needed in rapidly changing circumstances, i.e., a need for 'Plans B and $\mathrm{C}^{\prime}$;

- Breaks: more breaks need to be taken.

\subsubsection{Effects on Well-Being at Work: Both Groups}

Both informant groups reported positive effects on well-being at work. Remote work facilitated, enhanced, and saved work and working time, the working environment was calm, and control of the workload was easier. Many participants emphasized the impacts on the efficiency of work and the workflow. Positive features also included freedom, meaning, and creativity of work, which supported a balanced state of mind and a feeling of empowerment while surviving the Pandemic period. Common experiences were focused on absences, morbidity, and traveling, which were reduced.

Negative experiences of the more technology-intensive work and interaction and remote work during the Pandemic included many psychosocial and other kinds of effects on well-being at work. Furthermore, these effects were quite similar in both groups. Many expressed their experiences of isolation, working alone and loneliness, extra work, being hurried, increased workload, and rapid and unpredictable changes in work. The main stressors focused on health safety, protection, and masks in the workplaces and during customer interactions. Stressors increased mental pressure, strain, and fatigue, sick leaves, and absences. The Project staff reported physical and mental fatigue, decreased meaningfulness of work, and frustration. Some of them felt disappointment because of the cancellation of interesting events, occasions, and trips. In both groups, well-being at work weakened because of the low level of social contact and professional loneliness.

"Pandemic has mixed everything up. The work has become even more ambiguous."

"Has had to create and give of himself more and more, decreased motivation."

"The amount of work has increased, but no resources have been added. Overtime has increased, and I feel that pandemic has been the hardest part of my career."(Project, Developer)

Interestingly, only a few of the remotely working employees or professionals described the features of management or leadership while working remotely in exceptional circumstances or taking care of the employer's responsibilities during the Pandemic period. The most common thing people wrote about was the turnover of supervisors, low attendance, few face-to-face encounters, and more distant interactions than before the Pandemic. Among the responsibilities of employers, poor familiarization, low or depleted human resources, and increased workload were highlighted, the combined effect of which was perceived to be an increased workload and deterioration of well-being at work.

\subsection{The Power and Impact of Collaborative and Dialogical Development}

In autumn 2021, the post-measurement of the quality of working life questionnaire assessing the state of well-being at work in the pilot organizations was answered by 172 respondents of child welfare and family services and 53 respondents of services for the elderly. At the time of writing, another special education pilot had not yet responded to the post-measurement; thus, both pilots of special education have been excluded from these results. The results of the frequency analyses were combined from the five Likert options (1-5) into option 1 (Very good effectiveness/Very satisfied/Fully agree, etc., \%) and option 2 (Quite good effectiveness/Quite satisfied/Somewhat agree, etc., \%).

In total, 225 respondents assessed the effectiveness of collaborative and dialogic development of the Project by answering the following question: What kind of an effect has the dialogic and collaborative development had? The results showed that the experiences of the staff of the child welfare and family services and elderly services regarding the effectiveness of dialogic and collaborative development were very similar. The best impacts were focused on employee-management relationships, leadership, teams, workplace renewal and development, and information flow, as well as communication. Furthermore, 
improved job satisfaction was indicated by almost all the assessed variables. Most of the increased satisfaction was focused on the individual's team $(+10 \%)$, quality of services $(+6 \%)$, atmosphere of the workplace $(+5 \%)$, workplace community members' willingness to cooperate $(+4 \%)$, and customer relationships $(+3 \%)$.

According to the results of the pre-measurement in 2019, variables that promote wellbeing and coping at work included excessive workload and the mental and ethical burden of work. During the transition and COVID-19 phases, the workload (from 75\% to 81\%) and mental workload (from $91 \%$ to $89 \%$ ) increased. In contrast, the physical workload decreased (from 19\% to 16\%). The pre-measurement also showed an occupational overload $(13 \%)$, which suggests that the work and its demands were perceived to be too difficult for the individual's skills and competence. Occupational overload decreased somewhat $(-5 \%)$; however, occupational underemployment, which impairs well-being at work and makes work too easy for one's skills, remained unchanged. This further undermined the experience of well-being at work. A good result in terms of work control was that $5 \%$ more participants felt that their work, tasks, and responsibilities corresponded better to their abilities, skills, and competence than before the Pandemic.

In spring 2019, the results of leadership style were fairly good. The post-measurement in autumn 2021 showed that leadership improved, especially in the important features of dialogic leadership style [17]. The results improved, for example, in fairness $(+3 \%)$ and equality $(+4 \%)$, presence and accessibility $(+7 \%)$, management skills $(+3 \%)$, and the support of well-being at work $(+1 \%)$. There was a slight deterioration in only a few features of leadership: listening $(-3 \%)$, individual flexibility and job descriptions $(-4 \%)$, support and assistance $(-2 \%)$, and appreciation $(-2 \%)$.

The results of the post-measurement also highlighted an overall positive change in the characteristics of the workplaces, although the Project pilot organizations have been working in the Pandemic circumstances since March 2020. During the same period, the development of the Project was conducted remotely, and it was technology-based. The biggest positive changes were seen in the smoothness of cooperation between employees $(+5 \%)$ and in common understandings of the basic tasks $(+3 \%)$. In the pre-measurement, the worst results were in the rules of the game and adherence to them. Many workplaces agreed on the common rules of the game in the development session of the Project. There was a positive change in this important development theme, with $3 \%$ more respondents feeling involved in drawing up their own rules for the workplace, and $6 \%$ feeling better about following and committing to the agreed rules. There was also a positive change $(+6-8 \%)$ in workplace characteristics in terms of values and a fair and clear division of responsibilities and work.

\section{Discussion}

The research task was to analyze the challenges, learning experiences, and effects of the COVID-19 pandemic on the Social and Health Care and Special Education Development Project's dialogic development work. Particular interest was methodological: Is it possible to apply a Scandinavian dialogic and collaborative development model remotely and through technology? We were also interested in the kind of learning that took place, the positive and negative experiences, and the challenges encountered in the dialogic development participatory action research among different parties.

The experiences regarding technology, remote work, and dialogic development are viewed as neutral, positive, and negative. The use of technology during the Pandemic has clearly diversified and become more widespread and established in work, work communities, and experts developing working life. According to Richter [44] and Ruohomäki [27], COVID-19 and the related lockdowns in many countries have made digital work no longer just an option, but the new norm for many office workers, who have realized a new range of benefits of digital work tools. This trend was predicted by De' et al. [1] in their study on remote work and technology scenarios, emphasizing the normalization of new tech-driven work practices and transformations. Abrams [35] and Carrol and Conboy [41] also agree, 
suggesting that if this normalization process is performed correctly, it will have a positive effect on employee productivity, creativity, and morale.

The results showed that pilot organizations have learned dialogical action and the collaborative and dialogic development methods and tools, and development has been able to continue despite the Pandemic. Several positive effects on pilot organizations were realized. Many development goals were achieved, and the quality of working life indicators improved. The respondents of the post-measurement questionnaire assessed the effectiveness of the dialogic development of the Project.

However, in the pilot organizations and among the Project actors, it became apparent that dialogue interaction and development were significantly narrowed when done through remote working tools, for example, through Teams, which the Project has primarily used during the Pandemic. Given that non-verbal communication by all participants could not be observed simultaneously, much of the tone of interaction and verbal communication was overlooked. Thus, the dynamics of the group were also more difficult to perceive through these media than through face-to-face encounters, preferably through interaction and developmental dialogues within the dialogue circle. Similarly, the more difficult the development challenges were to be addressed, the more face-to-face, holistic communication and interaction were needed. We also felt that building important trust was easier through face-to-face work. Similarly, Gilpin-Jackson [19] emphasizes the importance of trust in a healthcare case study. In particular, so-called "difficult dialogues" and conflict solving call for immediate interaction and suitable psychical, social, and mental spaces [12,52].

There have been many positive experiences with remote work, and it is hoped that this will continue after the Pandemic. Digitalization and remote work have made work easier and more efficient. At the individual level, remote working has brought better work planning and flexibility, which were important factors that improved well-being and coping at work, increased the smoothness and efficiency of work, and saved time for actual work tasks as commuting and travel times have decreased. The Pandemic forced a digital leap in both the Project implementers and the pilot organizations, forcing all involved parties to learn and use new applications and programs, such as Teams, Zoom, Skype, and Presemo.

Richter [44] points out that remote work and digital working tools and environments during the Pandemic have given and can further provide flexibility to cope with the current, complex, and changing work and working life. Abrams [35] highlights the same positive features of remote work, as well as the impact on costs for both employers and employees. Employers can hire geographically distributed talent and reduce overhead expenses, whereas employees can gain flexibility, save time, and reduce travelling, transportation, and childcare costs. According to Ruohomäki [27], more than half of public sector employees were satisfied with remote work. At the individual and organizational levels, Schneider et al. [24] have found such protective factors as self-efficacy, coping ability, altruism, and organizational support.

Carrol and Conboy [41] emphasize the hard reality of COVID-19, which has led to radical changes for organizations and their workforces. Remote working has become an inevitable part of the changing nature of work, and new work models have had to be developed and deployed quickly. The results of this study reveal various concerns about the Pandemic, protection, and the search for solutions to increased work stress and reduced time for development work. Pilot organizations were forced to focus on basic tasks. Two pilot organizations stopped participating in the Project a few months before the Pandemic, and one immediately after the Pandemic began.

In too many pilot organizations, machines, devices, and equipment were inadequate, inappropriate, and not functional. In particular, many employees and professionals were burdened by the constant and perceived excessive use of technology and the continuous changes in equipment, systems, programs, connections, and associated problems, and they often felt overwhelmed with learning new systems and numerous passwords. The results of the literature review by Kautonen and Lehto [28] show that the psychosocial burden is caused by the remote work requirements and limited social contact, in particular. 
Deficiencies in digital tools and the skills to use them increase the workload experienced by employees. Individuals can reduce this psychosocial burden by creating clear routines, prioritizing work tasks, practicing various means of recovery, and pausing work often enough Organizational support and the training from supervisors also have a positive effect on the workload experienced by employees. According to Carroll and Conboy [41], strategic management together with IT managers must ensure the continuity of the work community and team productivity across the organization and provide guidance on normalizing new technology-driven work practices.

During remote work, psychosocial stress was caused by social isolation and reduced direct contact and interaction with coworkers, supervisors, and clients. Through technology, time could be used more efficiently. However, genuine face-to-face encounters, appointments, and meetings, as well as spontaneous informal corridor and coffee table discussions, were left out. The latter plays an important role in the natural pause and recovery from work. Free and spontaneous discussions and dialogues supporting the emergence of new ideas clearly diminished. Salmela-Aro et al. [31] study shows that during the spring of 2020, school principals experienced less enthusiasm and teachers experienced more exhaustion than in previous years due to the Pandemic.

The Project staff worked in universities and polytechnics, and their work was affected by the employer's regulations and restrictions during the Pandemic. Throughout the Project, the staff were forced to telecommute. Mäkikangas et al. [30] have reported similar results focusing on well-being at work among university personnel. Commitment to work during the remote work period was influenced by the employer's support for remote work, the self-initiated development of work, belief in one's ability, and the functioning of the home as a work environment. In conclusion, Mäkikangas et al. stress the importance of supporting remote work with remote management, promoting the importance of the functioning of the home for remote work, and the need to support employees individually in their remote work. According to Abrams [35], the impact of remote work and digitalization on productivity, creativity, and morale has been the subject of debate, especially in psychological research, primarily because working from home offers employees fewer opportunities to talk and network with their colleagues. Social and professional isolation as well as reduced direct contact and little or no social relationships with co-workers, have generally reduced well-being in remote work [27,28]. De' et al. and Ruohomäki [1,27] have found that the weakening of well-being at work is because of increased technostress issues and mental workload.

Experiences in learning new technology and good practices, as well as remote meeting programs, were very common among both groups. The skills and attitudes that were learned in relation to remote work, technology, and digitalization, as well as new ways to cooperate and interact remotely with clients, managers, and colleagues, are important meta-skills and competencies for future work and working life. The hope for the future is that customers' skills in the use of technology and in remote contacts will increase and improve. Warinowski et al. [23] highlight three aspects in particular from the different phases of the Pandemic among educational professions: general cognitive skills and agency, welfare skills, and equality. Additionally, the Project's pilot organizations and Project staff faced new challenges during the Pandemic related to developing and learning those skills, which appeared to be both strengthening factors of well-being at work and stressors. According to Postareff et al. [22], the results regarding teachers' well-being are worrying. Challenges to well-being have further increased as a result of the sudden changes in teaching arrangements caused by the Pandemic. The results of Postareff et al. [22] research show that remote schooling has negatively affected teachers' well-being at work.

Perhaps the most interesting result in the pilot social and healthcare workplaces was revealed in the post-measurement of the quality of working life questionnaire. Very few of the respondents narrated experiences of remote management and leadership. Some described supervisor work, mutual interaction, information flow, or employer responsibilities during the exceptional and rapidly changing Pandemic circumstances. Although 
not directly, the respondents said that the responsibilities and obligations of the employer and supervisors, mostly the negative aspects-problems and challenges related to remote working, technology, and digitalization, as well as skills gaps and training needs-are clearly the responsibility and obligation of employers.

According to Abrams [35] and Terkama-Moisio et al. [53], managers practicing in the field must better understand not if, but how, remote work is best conducted to maximize work output and well-being. Ruohomäki [27] points out that successful remote work solutions should be based on trust, joint planning, and employee self-direction. Aslan and Yuar [25] performed a literature analysis focusing on 400 healthcare professionals from six hospitals in four cities. A positive relationship was found between well-being at work and supervisor and co-worker support, and a negative relationship between well-being at work and emotional exhaustion.

According to Pekkola et al. [38], during the Pandemic, many academic leaders faced similar challenges in relation to crisis management [36], as reported in this study. The challenges focused on (1) a massive increase in emails and requests via electronic communications; (2) an uneven impact of the crisis on workload (i.e., key personnel were overloaded); (3) a lack of information on employees' performance and well-being; (4) the restrictive nature of formal communications about the crisis (i.e., the absence of face-to-face "coffee conversations" and adaptation to the new online format of "announcement mode" meetings); and (5) the stress of overlooking important information. Gilpin-Jackson [19] emphasizes the importance of leadership and trust in a complex and rapidly changing organizational environment, highlighting issues that are likely to be common, such as supervisor turnover, low attendance, distance, poor familiarization, limited human resources, and increased workload.

The biggest challenge of the study was the rich qualitative and quantitative data, which produced diverse results. Results could have been reported and analyzed in many different ways. The research methods proved to be very suitable, and several of them had already been recorded in the project implementation plan. The COVID-19 pandemic that began during the Project brought many development challenges, which were reflected in the results. For action researchers, the pandemic provided an unprecedented opportunity to analyze how dialogic development models can be implemented remotely and through technology. A question mapping the pilot organization staff's experiences of the Pandemic was added to the post-measurement of quality of working life questionnaire. The evaluation workshops of the COVID-19 pandemic on the dialogic and collaborative development and implementation of the project were also assessed in the evaluation workshops for the staff and management of the pilots.

\section{Conclusions}

The results showed that pilot organizations have learned the dialogic development method, and development has been able to continue despite the Pandemic. The power and impact of collaborative and dialogical development were also seen. In summary, the dialogic and participatory development had the best impact on team operations, workplace development and renewal, information flow and communication, employee-management relationships, and features of leadership style (fairness and equality, presence and accessibility, management skills, and support of well-being at work).

The results of the study highlighted many problems and challenges, as well as wideranging learning among both groups under study during the Pandemic. In summary, remote working, technology, and development are perceived to have become permanent, necessary, and appropriate aspects of working life. According to the results, the experiences among all of the studied groups' staff-child and family services, elderly services and special education-were very similar.

The work conditions and environments of remote working and technology are, by nature, physical, mental, and psychosocial stressors that directly impair well-being at work. 
Physical strain was also increased by deteriorating and reduced physical workspaces, both at home and in workplaces.

The respondents' experiences of appreciation, listening, support, and individual flexibility from their immediate superiors were somewhat impaired, although the Project provided support and supervision to the management, the supervisors, the immediate managers, and team leaders. In conclusion, these features may have been negatively affected by remote working, because they required immediate interaction and were difficult to implement remotely and through technology. Employers have a legal obligation to take care of their employees' working environment, work equipment, and well-being and safety at work, even in exceptional circumstances such as during the Pandemic. The results showed that these employers' responsibilities were partially neglected during the Pandemic.

In many ways, the results reflected the professional learning experiences and rapid reactions of the responsible experts (i.e., researchers, teachers, lecturers, and workplace developers) implementing and carrying out the Project. The work of a teacher, a workplace developer, and an action researcher are expert-level and require diverse skills. The Pandemic radically changed the basic work and project work of these professional groups. There was a rapid transition to remote work and distance learning, and the support of pupils and students and pilot organizations' staff started at the same time.

The effects of the Pandemic on the basic tasks of the pilot organization were partially positive and partially negative, and many challenges and problems were encountered. However, it should be noted that each pilot also had different circumstances during the Pandemic. Hence, the effects of the Pandemic were different. Therefore, broad generalization of the results is not possible. However, the results describe the general effects of the Pandemic in the context of Finnish public and private social and healthcare and special education.

To learn more about remote work and its implications for the future of work, psychologists are studying the benefits, drawbacks, and best practices of remote work [35]. A related and general line of further research is exploring how to maximize the effectiveness of geographically distributed workplaces, professionals, and teams that rely primarily on virtual means of communication. According to Mak and Kozlowksi [46], a related line of research is exploring how to maximize the effectiveness of geographically distributed virtual teams that rely primarily on virtual means of communication. The results of Virtaneva et al. [33] study on knowledge workers showed the positive influence of self-efficacy and teamwork on productivity during remote work.

Clearly, there is a need for wide-ranging dialogues with different parties when planning and outlining the ways in which future work will be carried out. There is an opportunity for employees and employers to reflect on how remote work, technology, and digitalization affect well-being and safety at work, features of work and tasks, management and leadership, social relationships, and interactions in the ongoing transformation of working life. Now is the time to have important dialogues about the changes in work and working life caused by the COVID-19 pandemic. The nature of these dialogues should be reflective and constructive, and all relevant stakeholders in organizations should be involved, because this is a common future of working life for all.

Author Contributions: Conceptualization, methodology, validation, formal analysis, data curation, writing - original draft preparation, and writing — review and editing, S.S. and K.L.; visualization, supervision, and project administration, S.S. All authors have read and agreed to the published version of the manuscript.

Funding: This research was funded by European Social Fund, Ministry of Social Affairs and Health, Finland. 11.2.2019 EURA 2014/6832/09 0201 01/2018/STM. Project code S21565.

Institutional Review Board Statement: The study did not require the consideration and approval of the Research Ethics Board and followed the guidelines of the Finnish Research Ethics Advisory Board.

Informed Consent Statement: Informed consent was obtained from all subjects involved in the study. 
Data Availability Statement: Data are not publicly available.

Acknowledgments: The authors thank the European Social Fund, Ministry of Social Affairs and Health, Finland, for supporting the project.

Conflicts of Interest: The authors declare no conflict of interest.

\section{References}

1. De', R.; Pandey, N.; Pal, A. Impact of Digital Surge during Covid-19 Pandemic: A Viewpoint on Research and Practice. Int. J. Inf. Manag. 2020, 55, 102-171. [CrossRef]

2. Miele, F.; Tirabeni, L. Digital Technologies and Power Dynamics in the Organization: A Conceptual Review of Remote Working and Wearable Technologies at Work. Sociol. Compass 2020, 2020, 127-195. [CrossRef]

3. Ennals, R. Gustavsen, Björn: Democratic Dialogue and Development. In The Palgrave Handbook of Organizational Change Thinkers; Springer: Berlin/Heidelberg, Germany, 2021; pp. 681-698.

4. Kalliola, S.; Mahlakaarto, S. Methods of Promoting Professional Agency at Work. Challenges 2020, 11, 30. [CrossRef]

5. Syvänen, S. Evil Eleven Syndrome. Dark Side of Workplaces. Pressures at Work and Costs of Non-Interference; VDM Verlag: Saarbrücken, Germany, 2010.

6. Syvänen, S. Työn Paineet Ja Puuttumattomuuden Kustannukset. Tutkimus Sisäisen Tehottomuuden Lähteistä Ja Vaikutuksista. Esimerkkikohteena Kuntien Sosiaalitoimen Vanhuspalveluja Tuottavat Työyhteisöt [Work Pressures and the Costs of Noninterference. A Study of the Sources and Effects of Internal Inefficiency. As an Example, Work Communities Providing Services for the Elderly in Municipal Social and Health Care Services]; Tampere University Press: Tampere, Finland, 2003.

7. Loppela, K. Ihminen Ja Työ-Keskustellen Työkuntoon. Työyhteisön Kehittäminen Työkykyä Ylläpitävän Toiminnan Viitekehyksessä. [Development of the Work Community Based on the Employees' Self-Evaluation]; Acta Universitas Tamperensis; Tampere University Press: Tampere, Finland, 2004.

8. Kalliola, S.; Nakari, R. The Resources for Renewal—a Participatory Approach to the Modernization of Municipal Organizations in Finland; John Benjamins: Amsterdam, The Netherlands, 1999.

9. Lehtonen, J.; Kalliola, S. Dialogue in Working Life. Research and Development in Finland; Peter Lang: Frankfurt, Germany, 2008.

10. Isaacs, W. Taking Flight: Dialogue, Collective Thinking, and Organizational Learning. Organ. Dyn. 1993, 22, 24-39. [CrossRef]

11. Isaacs, W. Dialogue and the Art of Thinking. A Pioneering Approach to Communication. Business and in Life; Currency: New York, NY, USA, 1999.

12. Syvänen, S.; Loppela, K.; Tikkamäki, K. Dialogisella Kehittämisellä Tuloksellisuutta, Työelämän Laatua Ja Uudistumista [Productivity, Quality of Working Life and Renewal through Dialogic Development] In Mihin työelämä on menossa? Tutkimuksen näkökulmia; Heiskanen, T., Syvänen, S., Rissanen, T., Eds.; PunaMusta Oy-Yliopistopaino: Tampere, Finland, 2019; pp. 171-216.

13. Syvänen, S.; Tikkamäki, K.; Loppela, K.; Tappura, S.; Kasvio, A.; Toikko, T. Dialoginen Johtaminen. Avain Tuloksellisuuteen, Työelämän Laatuun Ja Innovatiivisuuteen. [Dialogic Leadership-The Key to Productivity, Quality of Working Life and Innovativeness]; Tampere University Press: Tampere, Finland, 2015.

14. Kalliola, S.; Heiskanen, T. Experiences of Opening Up Communicative Spaces for Large-Scope Issues. Challenges 2021, 12, 25. [CrossRef]

15. Gustavsen, B.; Ekman, M.; Hofmaier, B. Concept-Driven Change: The Core Element in National Workplace Development and Program. Concept Transform. 1996, 1, 193-221. [CrossRef]

16. Syvänen, S. Developing Municipal Services for the Aged: The Role of Participatory Action Research and Concept-Driven Change. In The Resources for Renewal-a Participatory Approach to the Modernization of Municipal Organizations in Finland; Kalliola, S., Nakari, R., Eds.; John Benjamins: Amsterdam, The Netherlands, 1999; pp. 29-58.

17. Syvänen, S.; Loppela, K. Improving the Workplace: Top Seven Factors and Reflective Mirror of Dialogic Leadership. Nordic J. Work. Life Stud. Forthcom. 2022, 1, 23-43.

18. Gustavsen, B. Dialogue and Development. Theory of Communication, Action Research and the Restructuring of Working Life; Arbetslivscentrum: Stockholm, Sweden, 1992.

19. Gilpin-Jackson, Y. Practicing in the Grey Area between Dialogic and Diagnostic Organization Development Lessons from a Healthcare Case Study. OD Pract. 2013, 45, 60-66.

20. Gustavsen, B. Theory and Practice: The Mediating Discourse. In Handbook of Action Research; Reason, P., Brandbury, H., Eds.; Sage Publications: London, UK, 2006; pp. 17-26.

21. Kemmis, S. Participatory Action Research and the Public Sphere. Educ. Action Res. 2006, 14, 459-476. [CrossRef]

22. Postareff, L.; Lahdenperä, J.; Virtanen, V. The Role of Self-Compassion in Teachers' Psychological Well-Being in Face-to-Face and Online Teaching during COVID-19. Amm. Aikakausk. 2021, 23, 13-27.

23. Warinowski, A.; Metsäpelto, R.-L.; Heikkilä, M.; Mikkilä-Erdmann, M. Korona Opettajan Osaamisen Haastajana [COVID-19 Pandemic as a Challenger of Teacher Competence]. Kasv. Ja Aika 2021, 15, 73-78.

24. Schneider, J.; Talamonti, D.; Gibson, B.; Forshaw, M. Factors Mediating the Psychological Well-Being of Healthcare Workers Responding to Global Pandemics: A Systematic Review. J. Health Psychol. Online First. 2021. [CrossRef] [PubMed] 
25. Aslan, S.; Uyar, S. Within the Scope of Labor Relations: Relationships of Role Conflict and Ambiguity, Well-Being at Work, Emotional Exhaustion, Co-Worker and Supervisor Support, Reported Job Competence Variables. Ege Acad. Rev. 2021, 21, 247-262. [CrossRef]

26. Charalampous, M.; Grant, C.A.; Tramontano, C.; Michailidis, E. Systematically Reviewing Remote E-Workers' Well-Being at Work: A Multidimensional Approach. Eur. J. Work Organ. Psychol. 2019, 28, 51-73. [CrossRef]

27. Ruohomäki, V.; Tuomivaara, S.; Mattila-Holappa, P.; Monni, T.-M.; Perttula, P.; Alanko, T.; Toppinen-Tanner, S. Etätyö Koronaepidemian Hallitsemisessa Sekä Vaikutukset Työhyvinvointiin Ja Töiden Sujumiseen [Remote Work in the Management of the Covid-19 Pandemic and the Effects on Well-Being at Work and the Smooth Running of Work]. Psykologia 2020, 55, 388-395.

28. Kautonen, E.; Lehto, H. Kuvaileva Kirjallisuuskatsaus Etätyön Psykososiaalisten Kuormitustekijöiden Hallinnasta Ja Etätyöstä Palautumisesta [Descriptive Literature Review on the Management of Psychosocial Stressors in Remote Work and the Recovery from Telework]; Sosiaali-ja terveysalan johtaminen ja kehittäminen (YAMK); LAB University of Applied Sciences: Lahti, Finland, 2021.

29. Sainio, M.; Nurminen, T.; Hämeenaho, P.; Torppa, M.; Poikkeus, A.-M.; Aro, T. Koulujen Henkilökunnan Kokemukset Oppilaiden Hyvinvoinnista COVID-19-Etäkouluaikana: Osa Puhkesi Kukkaan. Muutamat Pitivät Rimaa Alhaalla [Experiences of School Staff on Student Wellbeing during COVID-19 Remota School: Some Blossomed. A Few Kept the Bar Down]. Oppimisen Ja Oppimisvaikeuksien Erit. 2020, 30, 12-32.

30. Mäkikangas, A.; Juutinen, S.; Oksanen, A.; Melin, H. Etätyö Ja Työn Imun Muutokset Kevään 2020 Koronakriisin Aikana Korkeakouluhenkilöstöllä [Remote Work and Changes in Work Engagement during the Coronavirus Crisis in Spring 2020 among Employees in Higher Education]. Psykologia 2020, 55, 408-425.

31. Salmela-Aro, K.; Upadyaya, K.; Hietajärvi, L. Suomalaisten Rehtorien Ja Opettajien Työhyvinvointiprofiilit Koronakeväänä [Work-Related Well-Being Profiles among Finnish School Teachers and Principals during the Spring of COVID-19]. Psykologia 2020, 55, 426-443.

32. Pöysä, S.; Pakarinen, E.; Lerkkanen, M.-K. Patterns of Teachers' Occupational Well-Being During the COVID-19 Pandemic: Relations to Experiences of Exhaustion, Recovery, and Interactional Styles of Teaching. Front. Educ. 2021, 6, 699785. [CrossRef]

33. Virtaneva, M.; Feshchenko, P.; Hossain, A.; Kariluoto, A.; Kaitila, P.; Himmanen, J.; Kultanen, J.; Kemell, K.-K.; Abrahamsson, P. COVID-19 Remote Work: Body Stress, Self-Efficacy, Teamwork, and Perceived Productivity of Knowledge Workers. In Proceedings of the 12th SCIS Conference 2021; Parmiggiani, E., Kempton, A., Mikalef, P., Eds.; Association for Information Systems: Atlanta, GA, USA, 2021; Volume 2021, p. 8.

34. Leskinen, T. Etätyö Yleistyi Eniten Aloilla Ja Alueilla, Joilla Sitä Ennen Tehtiin Vähiten [Telework Was Most Prevalent in the Sectors and Areas Where It Was Least Done Before]. Tieto Trendit 2021, 3, 29.

35. Abrams, Z. The Future of Remote Work. Monit. Psychol. 2019, 50, 54-60.

36. Mikusova, M.; Horvathova, P. Prepared for a Crisis? Basic Elements of Crisis Management in an Organisation. Econ. Res.-Ekon. 2019, 32, 1844-1868. [CrossRef]

37. Mysirlaki, S.; Paraskeva, F. Emotional Intelligence and Transformational Leadership in Virtual Teams: Lessons from MMOG. Leadersh. Organ. Dev. J. 2020, 41, 551-566. [CrossRef]

38. Pekkola, E.; Siekkinen, T.; Kujala, E.-N.; Kanniainen, J.-P.; Laihonen, H. An Assessment of COVID-19's Impact on Finnish University Leadership. Knowl. Manag. Res. Pract. Early online. 2021. [CrossRef]

39. Ciriello, R.; Richter, A.; Schwabe, G. The Paradoxical Effects of Digital Artefacts on Innovation Practices. Eur. J. Inf. Syst. 2019, 28, 149-172. [CrossRef]

40. Agerfalk, P.; Conboy, K.; Myers, M. Information Systems in the Age of Pandemics: COVID-19 and Beyond. Eur. J. Inf. Syst. 2020, 29, 203-207. [CrossRef]

41. Carroll, N.; Conboy, K. Normalising the "New Normal": Changing Tech-Driven Work Practices under Pandemic Time Pressure. Int. J. Inf. Manag. 2020, 55, 102-186. [CrossRef]

42. Kominers, S.; Stanton, C.; Wu, A.; Gonzalez, G. Zoom Video Communications: Eric Yuan's Leadership During COVID-19; Harvard Business School: Boston, MA, USA, 2020.

43. O'Leary, D. Evolving Information Systems and Technology Research Issues for COVID-19 and Other Pandemics. J. Organ. Comput. Electron. Commer. 2020, 30, 1-8. [CrossRef]

44. Richter, A. Locked-down Digital Work. Int. J. Inf. Manag. 2020, 55, 102-157. [CrossRef]

45. Lewandowska, A.; Stopa, M. The Impact of Innovative Professional Qualifications on the Sense of Employment Security: Evidence from Poland. Econ. Sociol. 2020, 13, 72-83. [CrossRef]

46. Mak, S.; Kozlowski, S. Virtual Teams: Conceptualization, Integrative Review, and Research Recommendations. In The Cambridge Handbook of Technology and Employee Behavior. Cambridge Handbooks in Psychology; Landers, R., Ed.; Cambridge University Press: Cambridge, UK, 2019; pp. 441-479.

47. Lämsä, J. Pandemia Haastaa Opettajia Ja Tutkijoita Muuttamaan Kysymyksiä Teknologiatuetusta Oppimisesta. Juu Vai Ei Digiteknologialle? [The Pandemic Is Challenging Teachers and Researchers to Change Questions about Technology-Enabled Learning. Whether or Not for Digital Technology?]. Kasvatus 2021, 52, 126-130.

48. Mononen, S. Kenttätyö Korona-Aikaan? What the Hela? [Field Work in Covid-19 Time? What the Hela?]. Ajankoht. Jyväskylän Yliop. Laitok. 2021, 2, 9.

49. Vuorinen, R.; Kettunen, J. Kansainvälinen Tilannekatsaus COVID-19 Pandemian Vaikutuksista Ohjaukseen [International Report on the Impact of the COVID-19 Pandemic on Governance]. Ajankoht. Elinikäisestä Ohjauksesta 2021, 2021, 18-19. 
50. Tuomi, J.; Sarajärvi, A. Laadullinen Tutkimus Ja Sisällönanalyysi: Uudistettu Laitos [Qualitative Research and Content Analysis: A Revised Edition]; Kustannusosakeyhtiö Tammi: Helsinki, Finland, 2018.

51. Laamanen, K.; Räsänen, T.; Juutilainen, A. Innostava Uudistuminen—Kestävä Kasvu [Inspiring Renewal—Sustainable Growth]; Teknologiainfo Teknova Oy: Tampere, Finland, 2016.

52. Watson, N.T.; Watson, K.L.; Stanley, C.A. Conflict Management and Dialogue in Higher Education: A Global Perspective; IAP: Charlotte, NC, USA, 2017.

53. Terkamo-Moisio, A.; Karki, S.; Kangasniemi, M.; Lammintakanen, J.; Häggman-Laitila, A. Towards Remote Leadership in Health Care: Lessons Learned from an Integrative Review. J. Adv. Nurs. 2021, 1-14. [CrossRef] [PubMed] 